\title{
Non-acidic bifunctional benzothiazole-based thiazolidinones with antimicrobial and aldose reductase inhibitory activity as a promising therapeutic strategy for sepsis
}

\author{
Antonios Kousaxidis $^{1} \cdot$ Lucia Kovacikova $^{2} \cdot$ Ioannis Nicolaou $^{1} \cdot$ Milan Stefek $^{2} \cdot$ Athina Geronikaki $^{1}$
}

Received: 17 June 2021 / Accepted: 27 July 2021 / Published online: 4 August 2021

(c) The Author(s), under exclusive licence to Springer Science+Business Media, LLC, part of Springer Nature 2021

\begin{abstract}
Sepsis is a life-threatening disease that affects millions of people worldwide. Microbial infections that lead to sepsis syndrome are associated with an increased production of inflammatory molecules. Aldose reductase has recently emerged as a molecular target that is involved in various inflammatory diseases, including sepsis. Herein, a series of previously synthesized benzothiazole-based thiazolidinones that exhibited strong antibacterial and antifungal activities has been evaluated for inhibition efficacy against aldose reductase and selectivity toward aldehyde reductase under in vitro conditions. The most promising inhibitor 5 was characterized with $\mathrm{IC}_{50}$ value of $3.99 \mu \mathrm{M}$ and a moderate selectivity. Molecular docking simulations revealed the binding mode of compounds at the active site of human aldose reductase. Moreover, owning to the absence of an acidic pharmacophore, good membrane permeation of the novel aldose reductase inhibitors was predicted. Excellent "drug-likeness" was assessed for most of the compounds by applying the criteria of Lipinski's "rule of five".
\end{abstract}

Graphical Abstract

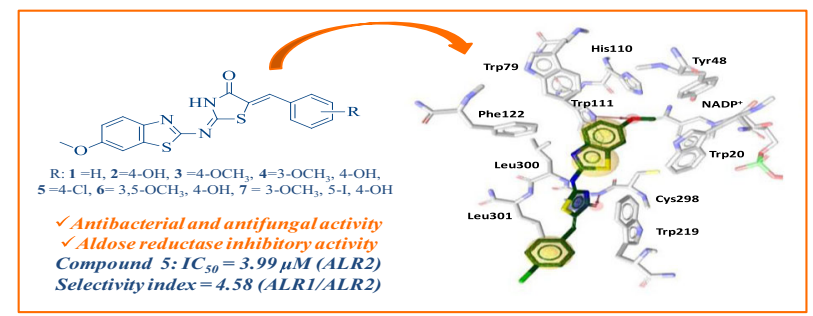

Keywords Antimicrobial $\cdot$ Sepsis $\cdot$ Aldose reductase $\cdot$ Selectivity $\cdot$ Molecular docking $\cdot$ Drug-likeness

Supplementary information The online version contains

supplementary material available at https://doi.org/10.1007/s00044021-02778-7.

Athina Geronikaki

geronik@pharm.auth.gr

1 School of Health, Department of Pharmacy, Aristotle University of Thessaloniki, Thessaloniki 54124, Greece

2 Institute of Experimental Pharmacology and Toxicology, CEM, SAS, Dúbravská cesta 9, 84104 Bratislava, Slovakia

\section{Introduction}

Sepsis is an important global health problem that causes life-threatening organ failure [1]. It may result from bacterial, viral, or fungal infections acquired in medical facilities. Microbial infections are one of the most common adverse consequences during the delivery of healthcare [2]. In 2017, an estimated number of 48.9 million incident cases of sepsis were recorded worldwide and 11.0 million sepsis-related deaths were reported, representing about $19.7 \%$ of all global deaths [1]. The morbidity and mortality in patients with sepsis remain high despite improvements in resuscitation antibiotics and other therapies [3]. 
Fig. 1 The role of aldose reductase (ALR2) in the LPSinduced inflammation. PLA2 phospholipase A2, PLC phospholipase C, DAG diacylglycerol, IP3 inositol trisphosphate, COX-2 cyclooxygenase-2, PGE prostaglandin E synthase, iNO inducible nitric oxide synthase

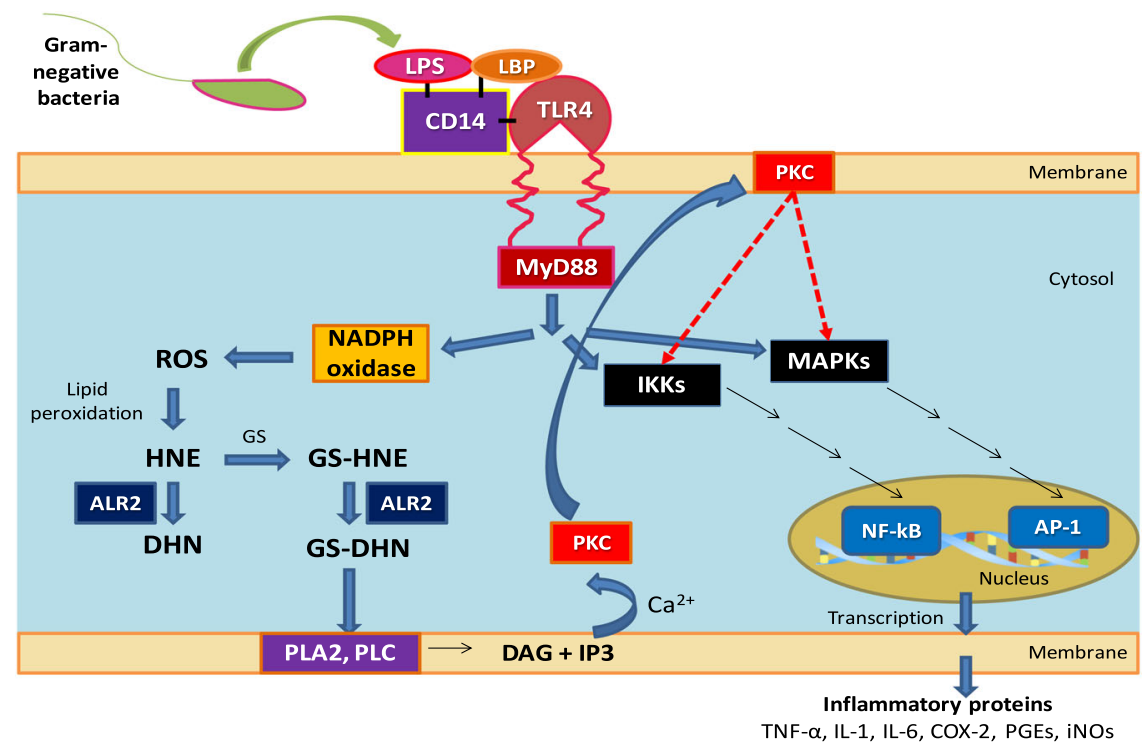

"Sepsis is an inflammatory disease mediated by a dysregulated host response to infection" [4]. Bacterial lipopolysaccharide (LPS), a highly pro-inflammatory endotoxin, is released from the surface of replicating Gram-negative bacteria into the circulation. LPS is recognized by a variety of cell types and induces the activation of a series of proinflammatory cytokines such as tumor necrosis factor- $\alpha$, interleukin-1, prostaglandins, and nitric oxide. These molecules depend on the nuclear factor kappa-light-chainenhancer of activated B cells (NF- $\mathrm{KB}$ ) [5]. Once LPS is bound to toll-like receptor 4 , it evokes the activation of IkappaB kinase complexes (IKKs) and mitogen-activated protein kinases (MAPKs) through myeloid differentiation primary response 88 protein. These protein kinase cascades end up with the activation of the redox-sensitive transcription factors such as NF-kB and activator protein-1, via nicotinamide adenine dinucleotide phosphate (NADPH) oxidase (Fig. 1) [6]. Even if the bacterial infection has been treated, the circulating endotoxins can cause a systemic inflammatory response. Therefore, controlling bacterial infection with a broad range of antibiotics is considered not adequate to medicate sepsis. It is rather essential to deactivate the immunogenic signals that produce inflammatory markers related to this disease $[3,7]$.

Aldose reductase (ALR2) belongs to the aldo-keto reductase (AKR) superfamily. This enzyme was first involved in the development of chronic diabetic complications. "ALR2 is a rate-limiting enzyme of the polyol pathway that converts glucose into sorbitol in the presence of reduced NADPH" [8]. NADPH is also required for glutathione (GS) reductase activity, which is a major antioxidant enzyme in many cells. Therefore, the competition between ALR2 and GS reductase for NADPH results in a redox imbalance, including reactive oxygen species production and oxidative stress [9]. In the past few years, ALR2 has emerged as the molecular target that mediates various inflammatory diseases, including sepsis [10]. ALR2 reduces one of the most abundant and toxic lipid aldehydes, 4-hydroxy-trans-2-nonenal (HNE), to 1,4-dihydroxynonene (DHN) and its GS conjugate, GS-HNE, to GS-DHN (Fig. 1) [8]. GS-DHN activates PKC and acts as the mediator of signaling pathways (Fig. 1) that cause cellular damage and inflammation [10].

There is accumulating evidence regarding the role of ALR2 in bacterial endotoxin-mediated inflammatory diseases. It has been established that ALR2 inhibition prevents endotoxin-induced lung injury [9], acute renal injury [11] as well as cardiomyopathy [5] in mice. Furthermore, ALR2 inhibition prevents the expression of NF-kB-dependent inflammatory cytokines by regulating the signals mediated by MAPKs, IKKs, and PKC [12]. Other studies [7, 9] show that ALR2 inhibitors can prevent the inflammation in the cecum ligation puncture model of polymicrobial sepsis in mice. Recently, ALR2 inhibition is believed to attenuate inflammation and ameliorate outcomes in patients with coronavirus disease 2019 (COVID-19) [13, 14]. Therefore, ALR2 inhibitors could provide a novel strategy for the prevention and/or treatment of sepsis complications, especially for COVID-19 patients who suffer from severe sepsis $[15,16]$ and patients who may be poor responders to conventional anti-inflammatory therapy.

In our previous papers, we mentioned the synthesis [1719] and the biological evaluation [18] of 5-arylidene-2-(6methoxybenzothiazol-2-ylimino)-4-thiazolidinones. It has been established that these benzothiazole-based thiazolidinones significantly inhibited the growth of a broad spectrum of Gram-positive and Gram-negative bacteria as well as fungi. Specifically, all compounds exhibited better antibacterial as well as antifungal activity than the reference 


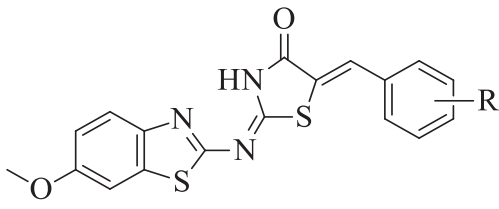

$\mathrm{R}: \mathbf{1}=\mathrm{H}, \mathbf{2}=4-\mathrm{OH}, \mathbf{3}=4-\mathrm{OCH}_{3}, \mathbf{4}=3-\mathrm{OCH}_{3}, 4-\mathrm{OH}$, $\mathbf{5}=4-\mathrm{Cl}, \mathbf{6}=3,5-\mathrm{OCH}_{3}, 4-\mathrm{OH}, 7=3-\mathrm{OCH}_{3}, 5-\mathrm{I}, 4-\mathrm{OH}$

Fig. 2 Structure of studied 5-arylidene-2-(6-methoxybenzothiazol-2ylimino)-4-thiazolidinones

drugs ampicillin and ketoconazole, respectively. Recently, much attention has been focused on thiazolidinone scaffold that demonstrates activity against ALR2 [20-34]. This led us to further screen a series of previously reported 5-arylidene-2-(6-methoxybenzothiazol-2-ylimino)-4-thiazolidinones [18] (Fig. 2) for their inhibitory activity toward ALR2 and selectivity against the homologous enzyme aldehyde reductase (ALR1). It is expected that bifunctional compounds possessing anti-inflammatory activity through ALR2 inhibition and antimicrobial activity could be a promising therapeutic approach for sepsis.

\section{Results and discussion}

\section{Drug design}

In our previous paper [17], we reported the design of a series of benzothiazole thiazolidinones based on our experience, literature survey and prediction of biologically activity spectra by computer program PASS [35, 36] as antimicrobial agents.

It was found that besides antimicrobial activity [17], compounds 1-7 may also possess antidiabetic activity through aldose reductase inhibition. According to PASS prediction, our compounds exhibited $P_{a}$ (probability to be active) values in the range of $0.171-0.226$ for antidiabetic activity. The fact that the $P_{a}$ values of compounds were less than 0.5 is an indication that their structures are different from that of PASS training set $[35,36]$. Thus, it can be established that they are new chemical entities (NCE).

On the other hand, generally, there is a great demand for multitarget directed drugs in treating diseases of multicomponent etiology, e.g., sepsis. Recent findings point to a key role of AR in the LPS-induced inflammation (Fig. 1). Several groups of thiazolidinone/thiazolidinedione as well as rhodanine-based inhibitors of ALR2 were designed recently [20-34]. The common features (Fig. 3) of all these inhibitors are a polar moiety capable of anchoring the anion-binding site of ALR2 and at least one aromatic ring.

Probed from these results, we decided to explore the probability of compounds 1-7 to inhibit aldose reductase under in vitro conditions.

\section{ALR2/ALR1 inhibitory activity}

ALR2 inhibitory activity was evaluated in partially purified rat lens ALR2. "It has been shown that human ALR2 exhibits $85 \%$ sequence homology to rat lens ALR2, while the catalytic active sites of both enzymes are considered identical" [37]. ALR2 inhibitory activity of compounds is expressed as $\mathrm{IC}_{50}$ values. Epalrestat was used as the reference compound. The results are shown in Table 1.

All compounds were also tested for their selectivity against ALR1. "ALR2 shares the highest degree of similarity with ALR1. The two enzymes exhibit $65 \%$ sequence homology, as well as structural homology. Since these closely related members of the AKR family are responsible for the reduction of toxic aldehydes, the simultaneous inhibition of ALR1/ALR2 could cause harmful side effects" $[8,38]$. ALR1 inhibitory activity is expressed as IC $_{50}$ values presented together with the calculated selectivity index (Table 1), along with the reference compound epalrestat $[39,40]$.

According to obtained results the order of activity against ALR2 can be presented as follows: $\mathbf{4}>\mathbf{2}>\mathbf{3}>\mathbf{5}>\mathbf{6}>\mathbf{1}=\mathbf{7}$, while against ALR1 as $\mathbf{4}>\mathbf{2}>\mathbf{5}>\mathbf{3}>\mathbf{6}>\mathbf{1}=\mathbf{7}$. It seems that the only difference between the activities of compounds against both enzymes is that compound $\mathbf{3}$ occupied the third place in order of activity against ALR1, while against ALR2 this position is occupied by compound $\mathbf{5}$. Thus, in both cases the most active compound was compound 4. Nevertheless, it was four-fold less active than reference drug epalrestat. The least active compounds appeared to be $\mathbf{1}$ and $\mathbf{7}$.

The study of structure-activity relationships revealed that the presence of the 4-hydroxyl and 3-methoxy -groups (4) in benzene ring is beneficial for both types of activity. Removal of 3-OMe group led to compound 2 with slightly decreased activity. Replacement of 4-OH with 4-OMe (3) and 4-Cl (5) substituents in benzene ring decreased more activity against ALR1 and ALR2, respectively. It is interesting to notice that introduction of the second methoxy group to compound $\mathbf{4}$ led to compound $\mathbf{6}$ that was the last among all active compounds, while replacement of 5-OMe group by iodine was detrimental resulting in totally inactive derivative 7 . Despite the fact that compounds $\mathbf{2}, \mathbf{3}$, and $\mathbf{4}$ are among the most active compounds in this series, they are nonselective $(\mathrm{SF}<1)$. On the contrary, compound 5 displayed a moderate inhibitory activity $\left(\mathrm{IC}_{50}=3.99 \mu \mathrm{M}\right)$ and the highest selectivity ( $\mathrm{SF}=4.58$ ) in this series. It is interesting to notice that compound $\mathbf{6}$ being twice less active than 5 also showed high selectivity $(\mathrm{SF}=4.00)$.

\section{Physicochemical properties}

Owing to the absence of the acidic function in compounds $\mathbf{1}, \mathbf{3}$, and $\mathbf{5}$, or the presence of the phenolic moiety of much 
Fig. 3 Thiazolidinone/ thiazolidinedione- and rhodanine-based inhibitors of aldose reductase.

Pharmacophoric features of aromatic ring and polar moiety are illustrated by yellow and red color, respectively

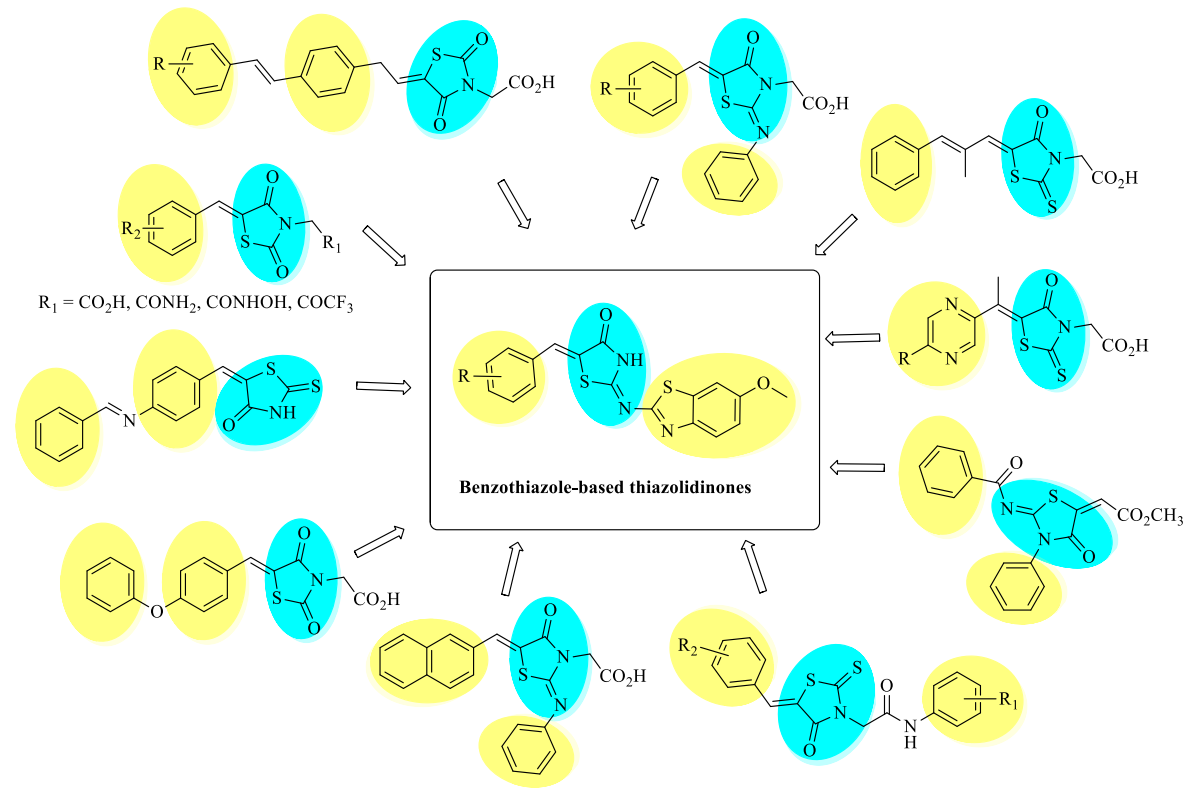

Table 1 Inhibitory activities of thiazolidinone derivatives 1-7 against the rat lens ALR2, the rat kidney ALR1, and the calculated selectivity index (SI) in comparison with standard epalrestat

\begin{tabular}{llll}
\hline Compound & \multicolumn{2}{l}{$\mathrm{IC}_{50}(\mu \mathrm{M})$} & $\begin{array}{l}\text { Selectivity index } \\
\text { (ALR1/ALR2) }\end{array}$ \\
\cline { 2 - 3 } & ALR2 & ALR1 & \\
\hline $\mathbf{1}$ & $>50$ & $>50$ & - \\
$\mathbf{2}$ & $1.30 \pm$ & $1.24 \pm 0.36$ & 0.95 \\
$\mathbf{3}$ & 0.20 & & \\
$\mathbf{4}$ & 4.35 & 4.21 & 0.97 \\
$\mathbf{5}$ & 0.83 & 0.61 & 0.73 \\
$\mathbf{6}$ & $3.99 \pm$ & $18.28 \pm$ & 4.58 \\
$\mathbf{7}$ & 0.14 & 1.55 & \\
Epalrestat [39] & 0.23 & - & 4.00 \\
Epalrestat [40] & $1.4^{\mathrm{a}}$ & 12.5 & - \\
\hline
\end{tabular}

${ }^{a}$ Human recombinant AKR1B1. Results are mean from two or mean \pm $\mathrm{SD}$ (standard deviation) from three independent measurements

higher pKa ( 9.7) in compounds $\mathbf{2}, \mathbf{4}, \mathbf{6}$, and 7, the all noncarboxylate aldose reductase inhibitors (ARIs) in this study are in unionized neutral form at physiological $\mathrm{pH}$. This ionization pattern is reflected by corresponding $\mathrm{pH}$ dependent profile of predicted distribution ratio $\log \mathrm{D}$ as shown in Fig. 4 for compounds $\mathbf{1}$ and 2, used as typical examples, in comparison with epalrestat. It is obvious that markedly higher $\log \mathrm{D}$ values are predicted for the studied compounds in comparison with acidic epalrestat.

As far as the physicochemical properties of the studied compounds are concerned, it was estimated that the moiety of thiazolidinone exhibits a pKa value of 7.2, while almost a $56 \%$ percentage of each compound was found in neutral

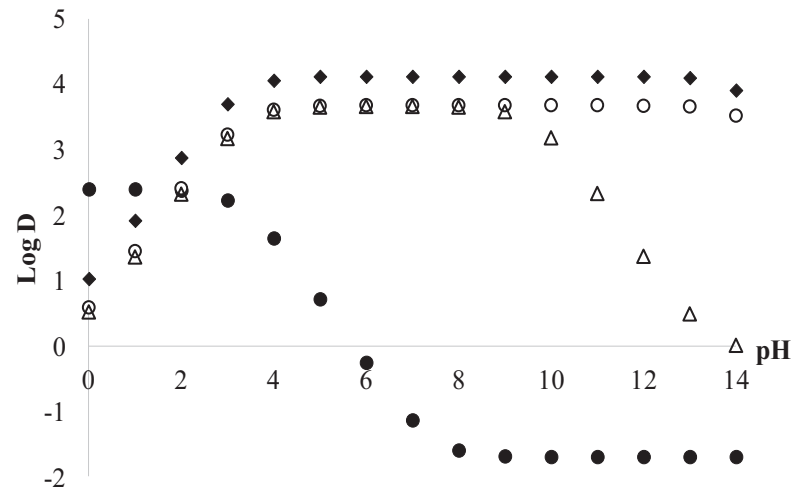

Fig. 4 Predicted pH-distribution profile of compounds $1(O), 2(\Delta), 5$ $(\diamond)$, and epalrestat $(\mathbf{O})$ in 1-octanol/buffer system (Pallas 3.1)

fraction at physiological blood $\mathrm{pH}$ (ADME Boxes 3.0). In addition, compounds $\mathbf{4}$ and $\mathbf{6}$ violate Veber's rule (topological polar surface area (TPSA) $>140 \AA$ ), while compound 7 demonstrates three violations (molecular weight $(\mathrm{MW})>$ $500, \log \mathrm{P}>5, \mathrm{TPSA}>140 \AA$ ). The rest of compounds successfully pass all these criteria and are estimated to be orally active. Furthermore, another calculated index that can be used in order to represent membrane permeation is the ratio of $\log \mathrm{D}_{7.4} / \log \mathrm{P}$ [37]. As can be seen in Table 2, all thiazolidinone derivatives have optimal values, close to 1 , for membrane permeation.

\section{Docking simulations}

We performed a docking simulation study based on the crystal structure of human ALR2 co-crystallized with epalrestat in order to investigate the ALR2-related binding 
Table 2 Physicochemical properties of studied compounds

\begin{tabular}{lllllllll}
\hline Compound & $\log \mathrm{D}^{\mathrm{a}}$ & $\log \mathrm{P}^{\mathrm{b}}$ & $\operatorname{logD} / \log \mathrm{P}^{\mathrm{c}}$ & $\mathrm{MW}^{\mathrm{d}}$ & $\mathrm{HBD}^{\mathrm{e}}$ & $\mathrm{HBA}^{\mathrm{f}}$ & $\mathrm{TPSA}^{\mathrm{g}}$ & $\mathrm{NRB}^{\mathrm{h}}$ \\
\hline $\mathbf{1}$ & 4.68 & 4.92 & 0.951 & 367.45 & 1 & 5 & 117.12 & 3 \\
$\mathbf{2}$ & 4.06 & 4.30 & 0.944 & 383.45 & 2 & 6 & 137.35 & 3 \\
$\mathbf{3}$ & 4.64 & 4.88 & 0.951 & 397.47 & 1 & 6 & 126.35 & 4 \\
$\mathbf{4}$ & 3.91 & 4.15 & 0.942 & 413.47 & 2 & 7 & 146.58 & 4 \\
$\mathbf{5}$ & 5.25 & 5.49 & 0.956 & 401.89 & 1 & 5 & 117.12 & 3 \\
$\mathbf{6}$ & 3.76 & 4.00 & 0.940 & 443.50 & 2 & 8 & 155.81 & 5 \\
$\mathbf{7}$ & 4.78 & 5.09 & 0.939 & 539.37 & 2 & 7 & 146.58 & 4 \\
\hline
\end{tabular}

${ }^{\mathrm{a}} \log \mathrm{D}$ represents the logarithm of the octanol-buffer distribution coefficient at $\mathrm{pH} 7.4$

${ }^{\mathrm{b}} \log \mathrm{P}$ represents the logarithm of octanol-water partition coefficient

${ }^{c} \log \mathrm{D} / \log \mathrm{P}$ value close to 1 represents high tissue penetration

${ }^{\mathrm{d}}$ Molecular weight $(\mathrm{MW}<500 \mathrm{Da})$

${ }^{\mathrm{e}}$ Hydrogen bond donors $(\mathrm{HBD} \leq 5)$

${ }^{\mathrm{f}}$ Hydrogen bond acceptors $(\mathrm{HBA} \leq 10)$

${ }^{\mathrm{g}}$ Topological polar surface area (TPSA $\leq 140 \AA$ )

${ }^{\mathrm{h}}$ Number of rotatable bonds $(\mathrm{NRB} \leq 10)$ mode in this series of compounds. It was found that most of compounds' binding modes (Fig. 5) overlapped with that of the co-crystallized ligand (epalrestat). The estimated binding energies of the complexes and the interactions with catalytic residues are displayed for each ligand including epalrestat in Table 3.

In particular, benzothiazole moiety of all derivatives except compound 5 (Fig. 6) fills up the hydrophobic pocket consisted mainly of Trp219, Ala299, Leu300, and Leu301 side chains in a similar way as styrene moiety of epalrestat (Figs. 6 and 7H). Hydrogen bonds are formed for all phenolic derivatives (Fig. 7B, D, F, G) between hydroxyl group and residues of Val47, Tyr48, and His110. Particularly, phenol moiety in compounds 2 and $\mathbf{4}$ effectively occupies the anion-binding pocket of ALR2 forming hydrogen bonds with His 110 and/or Tyr48 residues. This fact contributes to the high stabilization of the ligandenzyme complex and may explain the activity profile of compounds $\mathbf{2}$ and 4 . The nitrogen atom of benzothiazole moiety ( $\mathbf{1}$ and $\mathbf{2}$ ) is involved in hydrogen bond interactions with the backbone of Leu301 residue. In the case of derivative $\mathbf{2}$, an additional hydrogen bond is formed between imine-group and Ala299 residue of selectivity pocket.

Furthermore, the phenyl rings of derivatives 1-4 are exposed in a highly hydrophobic pocket surrounded by side chains of Trp20, Val47, Trp79, Trp111, and Phe122 residues. In addition, the carbonyl-group in thiazolidinone moiety of examined compounds $\mathbf{4}, \mathbf{5}$, and $\mathbf{7}$ acts as hydrogen bond acceptor (HBA) among the -NH- backbone of Leu300, Ala299, and Cys298 residues, respectively. Finally, the chloro-substituted derivative $\mathbf{5}$ adopts a different pose into the active site of human ALR2 (Figs. 6 and 7E). Specifically, the benzothiazole ring enters deep into the anion-binding site forming several hydrophobic interactions with the Trp20, Trp111, and Phe122 amino acids as

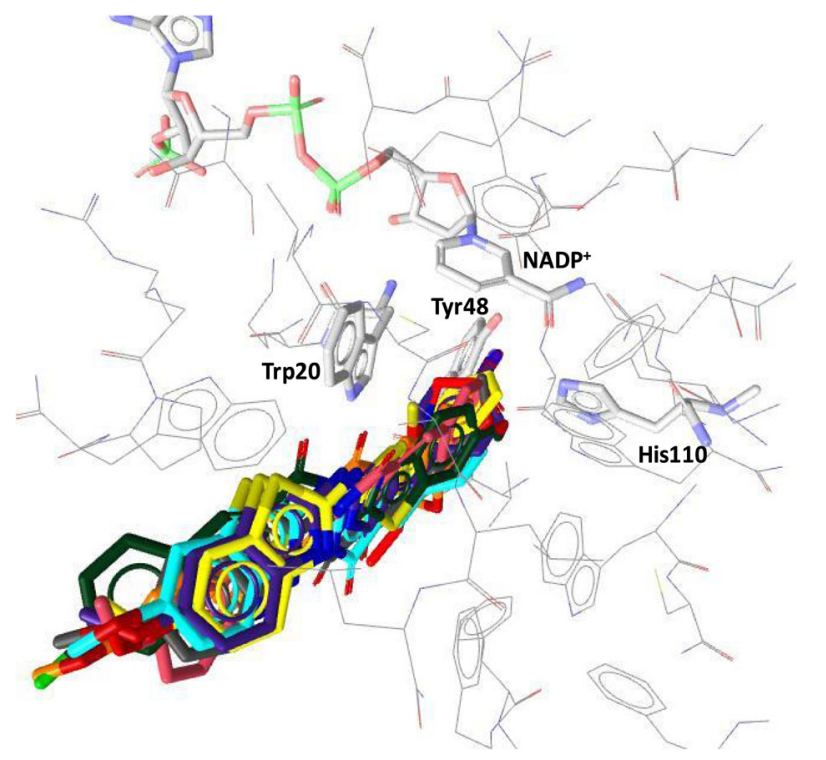

Fig. 5 Predicted binding modes for the studied compounds in the crystal structure of ALR2 (PDB ID: 4JIR). Main catalytic residues as well as $\mathrm{NADP}^{+}$in the anion-binding pocket are illustrated with gray color. Docked molecules are displayed as follows: 1 (yellow), 2 (purple), $\mathbf{3}$ (magenta), $\mathbf{4}$ (pink), $\mathbf{5}$ (green), $\mathbf{6}$ (dark gray), $\mathbf{7}$ (orange)

well as a hydrogen bond at $3.32 \AA$ between Trp111 residue and methoxy group of inhibitor. The 4-chlorophenyl moiety enters the selectivity pocket by interacting with side chain of Leu301. It was also found that the hydrogen bond between Ala299 and carbonyl-group is the least distant $(2.88 \AA)$ in comparison with the same hydrogen bonds of derivatives $\mathbf{4}$ and $\mathbf{7}$, while the thiazolidinone moiety forms $\pi-\pi$ stacked interactions with the side chain of Trp219.

Moreover, docking simulation of compound $\mathbf{6}$ showed that the hindered phenol moiety cannot form any hydrophobic interaction with anion-binding pocket, 
Table 3 Estimated binding energies and interactions with residues according to docking analysis \begin{tabular}{ll}
\hline Compound & $\begin{array}{l}\text { Est. binding energy (kcal/ Residues } \\
\text { mol) }\end{array}$
\end{tabular}

\begin{tabular}{lll}
\hline $\mathbf{1}$ & -7.60 & NADP,+ Trp20, Tyr48, Val47, Ala299, Trp219, Leu301 \\
$\mathbf{2}$ & -7.36 & NADP,+ Val47, His110, Tyr48, Trp20, Ala299, \\
& Trp219, Leu301 \\
$\mathbf{3}$ & -6.37 & Phe122, Va147, Trp20, Trp79, Trp219, Leu301 \\
$\mathbf{4}$ & -6.37 & NADP,+ Trp111, His110, Trp79, Trp20, Leu300, \\
& & Trp219, Leu301 \\
$\mathbf{5}$ & -7.34 & Trp111, Trp20, Phe122, Ala299, Trp219, Leu301 \\
$\mathbf{6}$ & -6.32 & Tyr48, Leu301, Trp219, Ala299 \\
$\mathbf{7}$ & -6.10 & Val47, Cys298, Leu301, Trp219, Ala299 \\
Epalrestat & -7.65 & Tyr48, Trp111, Leu300, Trp219, Ala299, Phe122, Leu301 \\
\hline
\end{tabular}

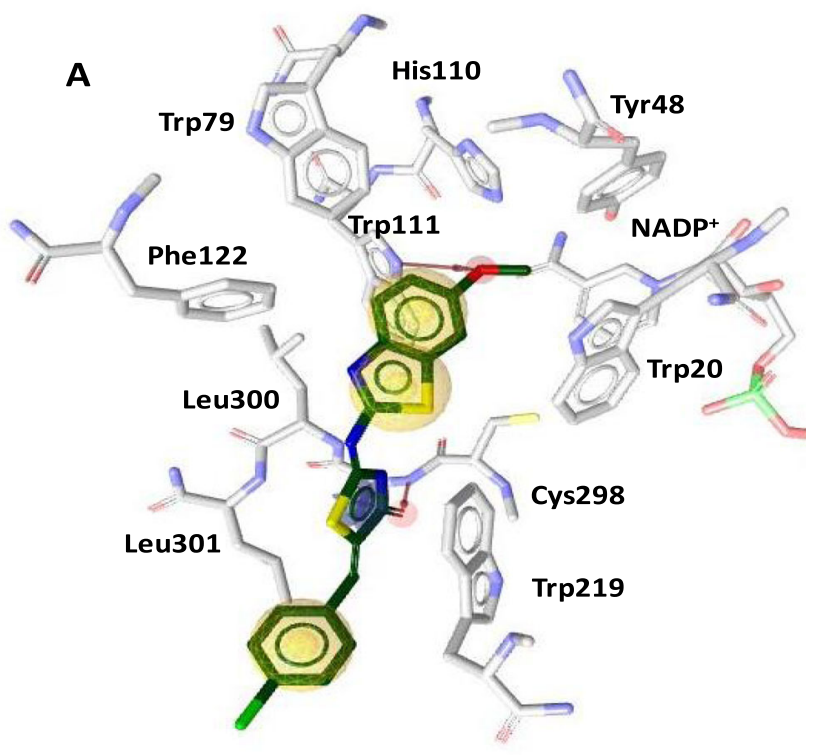

Fig. 6 Pharmacophoric features of compound 5 (A) and epalrestat (B) after molecular docking in the human crystal structure of ALR2 (PFB ID: 4JIR). Hydrophobic interactions are illustrated as yellow spheres,

whereas hydroxyl group participates only in one hydrogen bond with Tyr48 residue. This fact may explain the moderate activity of compound $\mathbf{6}$ in comparison with compounds $\mathbf{2}$ and $\mathbf{4}$. In addition, the benzothiazole ring occupies the selectivity pocket forming hydrophobic interactions with the side chains of Trp219, Ala299, and Leu301 residues. Although compounds 5 and $\mathbf{6}$ appeared to adopt different biding modes, the hydrophobic interactions with these residues may explain their selectivity profile.

\section{Conclusion}

Sepsis is an inflammatory immune response triggered by infections. Although there are several antibiotics and

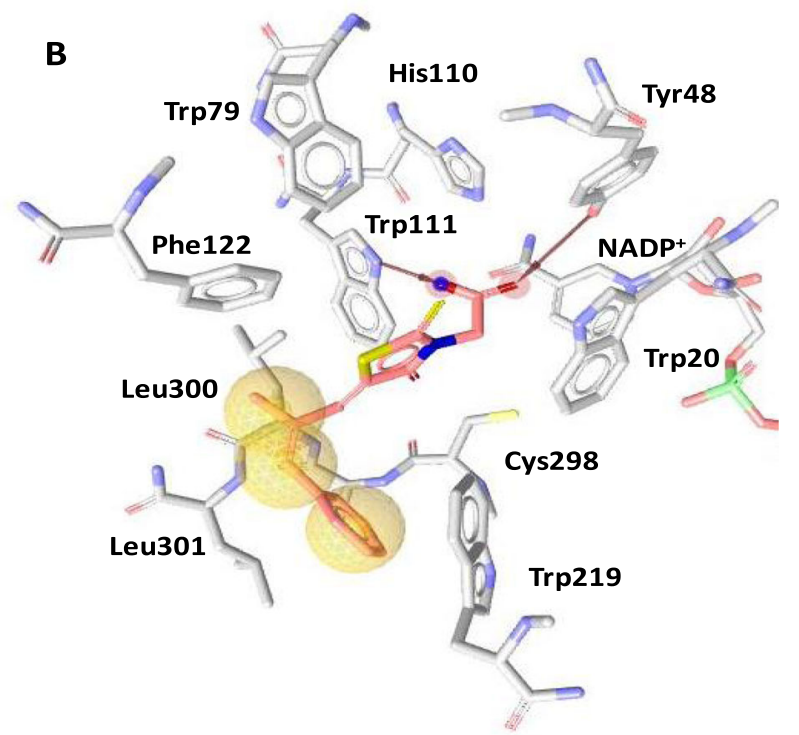

$\pi-\pi$ interactions as blue rings, and hydrogen bonds as red (acceptor) and green (donor) arrows

anti-inflammatory drugs, it is still an urgent need to discover new therapeutic molecules acting upon different mechanisms to effectively fight both microbial infections and sepsis-induced inflammation. In the past few years, ALR2 has emerged as a novel target associated with systemic inflammation in the progression of a variety of diseases including sepsis. A series of novel 5-arylidene2-(6-methoxybenzothiazol-2-ylimino)-4-thiazolidinones with potent antibacterial and antifungal effects have been evaluated for their ALR2 inhibitory activity and their selectivity against the homologous enzyme ALR1. The most promising derivative in this series was found to be compound 5 that exhibits satisfactory potency $\left(\mathrm{IC}_{50}=\right.$ $3.99 \mu \mathrm{M})$ and more than four-fold selectivity for ALR2 toward ALR1. Furthermore, the docking simulation of this promising compound into the human ALR2 enzyme 


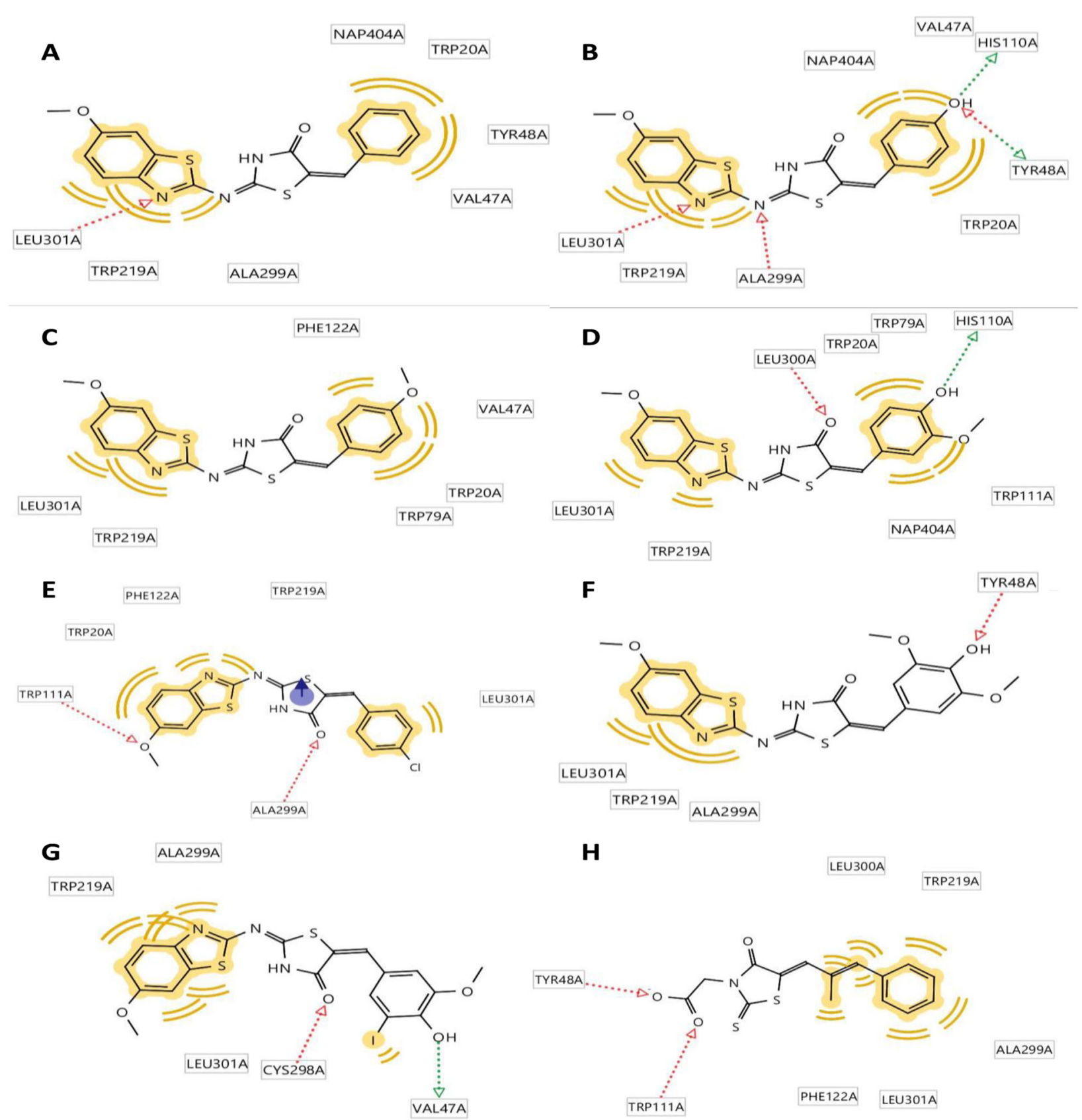

Fig. 7 2D representation of the binding modes of compounds $\mathbf{1}(\mathbf{A}), \mathbf{2}(\mathbf{B}), \mathbf{3}(\mathbf{C}), \mathbf{4}(\mathbf{D}), \mathbf{5}(\mathbf{E}), \mathbf{6}(\mathbf{F})$, and $7(\mathbf{G})$ as well as epalrestat $(\mathbf{H})$ at the active site of human ALR2

revealed that the benzothiazole moiety is exposed in the active site in which a hydrogen bond interaction is formed between methoxy group and Trp111. In addition, the thiazolidinone ring occupies the area around $\operatorname{Trp} 219$ residue, while the 4-chlorophenyl moiety is surrounded by a second hydrophobic pocket. According to the prediction of physicochemical properties, compound $\mathbf{5}$ demonstrated optimal oral bioavailability and safety profile, while it possesses antimicrobial activity against a wide range of bacterial and fungal infections. We hope that the results of this study could enhance the research interest related to multi-effective compounds for the treatment of sepsis.

\section{Experimental}

\section{Chemistry}

The syntheses as well as the elemental and spectroscopic analyses of the titled compounds were performed according to previously published processes [17-19]. 
Synthesis of (Z)-5-benzylidene-2-((6-methoxybenzo[d] thiazol-2-yl)imino)thiazolidin-4-one (1)

Yield: $89.4 \%$; mp $241-243{ }^{\circ} \mathrm{C}$ (Dioxane); IR (Nujol) $\nu_{\max }$ 1605, $1718(\mathrm{C}=\mathrm{O}), 2342(\mathrm{C}=\mathrm{C}) \mathrm{cm}^{-1} ;{ }^{1} \mathrm{H}$ NMR (DMSO$\mathrm{d} 6 ; 125 \mathrm{MHz}) \delta 4.00\left(\mathrm{~s}, 3 \mathrm{H},-\mathrm{OCH}_{3}\right), 7.00-7.04(\mathrm{~m}, 3 \mathrm{H}$, benz), 7.48-7.51 (m, 2H, Ph-H), 7.52-7.68 (m, 4H, Ph-H, benz), 7.83 (s, 1H, $\mathrm{ArCH}=), 12.17(\mathrm{~s}, 1 \mathrm{H},-\mathrm{NH}) ;{ }^{13} \mathrm{C} \mathrm{NMR}$ (DMSO-d6; $125 \mathrm{MHz}) \delta 55.54\left(\mathrm{O}-\mathrm{CH}_{3}\right), 104.92,114.76$, $119.51,127.03,128.12,128.14,128.21,128.24,131.14$, $132.22,135.84,145.20,152.03,156.72,158.86,(\mathrm{C}=\mathrm{O})$, 174.44; Anal. Calcd. for $\mathrm{C}_{18} \mathrm{H}_{13} \mathrm{~N}_{3} \mathrm{O}_{2} \mathrm{~S}_{2}$ (\%): C, 58.84; $\mathrm{H}$, 3.57; N, 11.44. Found (\%): C, 58.81; H, 3.59; N, 11.42 .

\section{Synthesis of (Z)-5-(4-hydroxybenzylidene)-2-((6-} methoxybenzo[d]thiazol-2-yl)imino)thiazolidin-4-one (2)

Yield: $90.8 \%$; mp 293-294 ${ }^{\circ} \mathrm{C}$ (Dioxane); IR (Nujol) $\nu_{\max }$ 1602, $1718(\mathrm{C}=\mathrm{O}), 2342(\mathrm{C}=\mathrm{C}), 3390(\mathrm{OH}) \mathrm{cm}^{-1} ;{ }^{1} \mathrm{H}$ NMR (DMSO-d6; $125 \mathrm{MHz}) \delta 3.81$ (s, 3H, $-\mathrm{OCH}_{3}$ ), 7.07-7.10 (m, 3H, benz), 7.54-7.67 (m, 4H, Ph-H), 7.85 (d, $\mathrm{J}=8.7,1 \mathrm{H}), 10.37(\mathrm{~s}, 1 \mathrm{H},-\mathrm{OH}), 12.72(\mathrm{~s}, 1 \mathrm{H},-\mathrm{NH}) ;{ }^{13} \mathrm{C}$ NMR (DMSO-d6; $125 \mathrm{MHz}) \delta 55.52\left(\mathrm{O}-\mathrm{CH}_{3}\right), 104.91$, $114.72,115.08,115.10,119.71,127.64,130.81,130.82$, 131.12, 132.07, 135.84, 145.19, 152.04, 156.71, 157.72 (C$\mathrm{OH}), \quad 167.84 \quad(\mathrm{C}=\mathrm{O}), \quad 174.43$; Anal. Calcd. for $\mathrm{C}_{18} \mathrm{H}_{13} \mathrm{~N}_{3} \mathrm{O}_{3} \mathrm{~S}_{2}(\%)$ : C, 56.38; H, 3.42; N, 10.96. Found (\%): C, 56.42; H, 3.39; N, 10.94 .

\section{Synthesis of (Z)-2-((6-methoxybenzo[d]thiazol-2-yl)imino)-} 5-(4-methoxybenzylidene)thiazolidin-4-one (3)

Yield: $51.6 \%$; mp $238-240{ }^{\circ} \mathrm{C}$ (Dioxane); IR (Nujol) $\nu_{\max }$ 1602, $1718(\mathrm{C}=\mathrm{O}), 2342(\mathrm{C}=\mathrm{C}) \mathrm{cm}^{-1} ;{ }^{1} \mathrm{H}$ NMR (DMSOd6; $125 \mathrm{MHz}) \delta 3.88$ (s, 6H, $\left.-\mathrm{OCH}_{3}\right), 6.98$ (s, 2H, benz), 7.69 (s, 1H, benz), 7.84-791 (m, 2H, Ph-H), 8.25 (d, J=7.5, $2 \mathrm{H}, \mathrm{Ph}-\mathrm{H}), 8.98$ (s, $1 \mathrm{H}, \mathrm{ArCH}=), 9.44(\mathrm{~s}, 1 \mathrm{H},-\mathrm{NH}) ;{ }^{13} \mathrm{C}$ NMR (DMSO-d6; $125 \mathrm{MHz}) \delta 55.88\left(2 \mathrm{C}, \mathrm{O}-\mathrm{CH}_{3}\right), 104.87$, 114.03, 114,05, 114.97, 118.21, 127.54, 130.11, 131.91, $132.12, \quad 145.20,152.07,156.84\left(\mathrm{C}-\mathrm{OCH}_{3}\right), 159.03(\mathrm{C}-$ $\left.\mathrm{OCH}_{3}\right), \quad 167.21(\underline{\mathrm{C}}=\mathrm{O}), \quad 174.41$; Anal. Calcd. for $\mathrm{C}_{19} \mathrm{H}_{15} \mathrm{~N}_{3} \mathrm{O}_{3} \mathrm{~S}_{2}(\%)$ : C, 57.41; H, 3.80; $\mathrm{N}, 10.57$. Found (\%): C, 57.40; H, 3.82; N, 10.55 .

Synthesis of (Z)-5-(4-hydroxy-3-methoxybenzylidene)-2-((6methoxybenzo[d]thiazol-2-yl)imino) thiazolidin-4-one (4)

Yield: $74.0 \%$; mp $238-240{ }^{\circ} \mathrm{C}$ (Dioxane); IR (Nujol) $\nu_{\max }$ 1602, $1718(\mathrm{C}=\mathrm{O}), 2342(\mathrm{C}=\mathrm{C}), 3390(\mathrm{OH}) \mathrm{cm}^{-1} ;{ }^{1} \mathrm{H}$ NMR (DMSO-d6; $125 \mathrm{MHz}) \delta 3.82\left(\mathrm{~s}, 3 \mathrm{H},-\mathrm{OCH}_{3}\right), 3.90$ $\left(\mathrm{s}, 3 \mathrm{H},-\mathrm{OCH}_{3}\right), 7.06-7.11(\mathrm{~m}, 1 \mathrm{H}, \mathrm{Ph}-\mathrm{H}), 7.32(\mathrm{~s}, 1 \mathrm{H}$, benz), 7.54-7.78 (m, 4H, Ph-H, benz, $\mathrm{ArCH}=), 10.47$ (s, $1 \mathrm{H},-\mathrm{OH}), 12.78$ (s, 1H, $-\mathrm{NH}) ;{ }^{13} \mathrm{C}$ NMR (DMSO-d6;
$125 \mathrm{MHz}) \delta 55.79\left(\mathrm{O}-\mathrm{CH}_{3}\right), 55.82\left(\mathrm{O}-\mathrm{CH}_{3}\right), \quad 104.01$, $114.72,115.01,118.24,127.12,128.00,129.66,130.01$, $134.40,145.19,152.02,155.14(\mathrm{C}-\mathrm{OH}) 156.77\left(\mathrm{C}-\mathrm{OCH}_{3}\right)$, 158.83, 167.55(C=O), 174.44; Anal. Calcd. for $\mathrm{C}_{20} \mathrm{H}_{17} \mathrm{~N}_{3} \mathrm{O}_{4} \mathrm{~S}_{2}(\%)$ : C, 56.19; H, 4.01; N, 9.83. Found (\%): C, 56.12; H, 4.04; N, 9.82.

Synthesis of (Z)-5-(4-chlorobenzylidene)-2-((6methoxybenzo[d]thiazol-2-yl)imino)thiazolidin-4-one (5)

Yield: $84.0 \%$; mp $280-281{ }^{\circ} \mathrm{C}$ (Dioxane); IR (Nujol) $\nu_{\max }$ 1602, $1722(\mathrm{C}=\mathrm{O}), 2384(\mathrm{C}=\mathrm{C}) \mathrm{cm}^{-1} ;{ }^{1} \mathrm{H}$ NMR (DMSO$\mathrm{d} 6 ; 125 \mathrm{MHz}) \delta 3.82\left(\mathrm{~s}, 3 \mathrm{H},-\mathrm{OCH}_{3}\right), 7.02-7.10(\mathrm{~m}, 1 \mathrm{H}$, $\mathrm{Ph}-\mathrm{H}$ ), 7.40-7.92 (m, 7H, Ph-H, benz, ArCH=), 12,19 (s, $1 \mathrm{H},-\mathrm{NH}) ;{ }^{13} \mathrm{C}$ NMR (DMSO-d6; $\left.125 \mathrm{MHz}\right) \delta 55.58(\mathrm{O}-$ $\left.\mathrm{CH}_{3}\right), 104.88,114.69,118.02,128.51,128.62,128.63$, $129,56,131.44,132.03,132.12,133.64,145.20,152.02$, $156.74\left(\mathrm{C}-\mathrm{OCH}_{3}\right), 157.81,167.85(\mathrm{C}=\mathrm{O}), 174.60$; Anal. Calcd. for $\mathrm{C}_{18} \mathrm{H}_{12} \mathrm{ClN}_{3} \mathrm{O}_{2} \mathrm{~S}_{2}(\%)$ : C, 53.79; $\mathrm{H}, 3.01 ; \mathrm{N}$, 10.46. Found (\%): C, 53.84; H, 2.87; N, 10.44.

Synthesis of (Z)-5-(4-hydroxy-3,5-dimethoxybenzylidene)-2((6-methoxybenzo[d]thiazol-2-yl) imino)thiazolidin-4-one (6)

Yield: 61.3\%; mp 269-271 ${ }^{\circ} \mathrm{C}$ (Dioxane); IR (Nujol) $\nu_{\max }$ 1602, $1730(\mathrm{C}=\mathrm{O}), 2384(\mathrm{C}=\mathrm{C}), 3390(\mathrm{OH}) \mathrm{cm}^{-1} ;{ }^{1} \mathrm{H}$ NMR (DMSO-d6; $125 \mathrm{MHz}) \delta 3.79$ (s, 3H, - $\mathrm{OCH}_{3}$ benz), 3.88 (s, 6H, 3-OCH $3, \mathrm{Ph}), 7.00-7.04$ (s, 2H, benz), 7.16 (s, 1H, Ph-H), 7.16 (s, 1H, Benz) 7.66-7.79 (m, 2H, Ph-H, $\mathrm{ArCH}=), 9.39(\mathrm{~s}, 1 \mathrm{H},-\mathrm{OH}), 12.71(\mathrm{~s}, 1 \mathrm{H},-\mathrm{NH}) ;{ }^{13} \mathrm{C}$ NMR (DMSO-d6; $125 \mathrm{MHz}) \delta 55.86\left(\mathrm{O}-\mathrm{CH}_{3}\right), 56.14(\mathrm{O}-$ $\left.\mathrm{CH}_{3}\right), 56.15\left(\mathrm{O}-\mathrm{CH}_{3}\right), 103.93,103.94,104.01,114.83$, 118.25, 129.65, 131.91, 133.42, 136.65 (C-OH) 145.20, 148.72, 148.78, 152.01, $156.84\left(\mathrm{C}-\mathrm{OC}_{3}\right), 158.81$, $167.53(\mathrm{C}=\mathrm{O}), 174.47$; Anal. Calcd. for $\mathrm{C}_{20} \mathrm{H}_{17} \mathrm{~N}_{3} \mathrm{O}_{5} \mathrm{~S}_{2}$ (\%): C, 54.16; H, 3.86; N, 9.47. Found (\%): C, 54.18; H, $3.88 ; \mathrm{N}, 9.43$.

Synthesis of (Z)-5-(4-hydroxy-3-iodo-5methoxybenzylidene)-2-((6-methoxybenzo[d]thiazol-2-yl) imino)thiazolidin-4-one (7)

Yield: $72.9 \%$; mp 288-289 ${ }^{\circ} \mathrm{C}$ (Dioxane); IR (Nujol) $\nu_{\max }$ 1602, $1730(\mathrm{C}=\mathrm{O}), 2384(\mathrm{C}=\mathrm{C}), 3390(\mathrm{OH}) \mathrm{cm}^{-1} ;{ }^{1} \mathrm{H}$ NMR (DMSO-d6; $125 \mathrm{MHz}) \delta 3.82$ (s, 3H, $-\mathrm{OCH}_{3}$ ), 3.90 $\left(\mathrm{s}, 3 \mathrm{H}, 3-\mathrm{OCH}_{3} \mathrm{Ar}\right), 7.08(\mathrm{~s}, 1 \mathrm{H}, \mathrm{Ph}-\mathrm{H}), 7.28-7.38(\mathrm{~m}$, $2 \mathrm{H}, \mathrm{Ph}-\mathrm{H}$, benz), 7.58-7.76 (m, 3H, benz, $\mathrm{ArCH}=)$, 10.47 (s, 1H, -OH), 12.77 (s, 1H, $-\mathrm{NH}) ;{ }^{13} \mathrm{C} \mathrm{NMR}$ (DMSO-d6; $125 \mathrm{MHz}) \delta 55.88\left(\mathrm{O}-\mathrm{CH}_{3}\right), 56.07\left(\mathrm{O}-\mathrm{CH}_{3}\right)$, 88.42 (C-I), 104.97, 110.02, 114.76, 118.22, 127.32, 130.24, 130.25, 133.40, 145.21, $149.90(\mathrm{C}-\mathrm{OH}) 151.98$, $152.82,156.83\left(\mathrm{C}-\mathrm{OCH}_{3}\right), 158.95,167.51 \quad(\mathrm{C}=\mathrm{O})$, 
174.52; Anal. Calcd. for $\mathrm{C}_{19} \mathrm{H}_{14} \mathrm{IN}_{3} \mathrm{O}_{4} \mathrm{~S}_{2}$ (\%): C, 42.31; H, 2.62; I, 23.53; N, 7.79. Found (\%): C, 42.29; H, 2.61; I, 23.50; N, 7.80.

\section{Biological evaluation}

\section{Antimicrobial assays}

The antibacterial activity of thiazolidinone derivatives was tested against human pathogenic bacteria, including the Gram-negative bacteria: Escherichia coli (ATCC 35210), Enterobacter cloacae, Pseudomonas aeruginosa (ATCC 27853), Salmonella typhimurium (ATCC 13311), and the Gram-positive bacteria: Listeria monocytogenes (NCTC 7973), Bacillus cereus (clinical isolate), Micrococcus flavus (ATCC 10240), and Staphylococcus aureus (ATCC 6538). In addition, eight fungi species were used for the evaluation of compounds' antifungal activity, including Aspergillus niger (ATCC 6275), Aspergillus ochraceus (ATCC 12066), Aspergillus fumigatus (ATCC 1022), Aspergillus versicolor (ATCC 11730), Penicillium funiculosum (ATCC 36839), Penicillium ochrochloron (ATCC 9112), Penicillium verrucosum var. cyclopium (food isolate), Trichoderma viride (IAM 5061), and Candida albicans (human isolate). The aforementioned bioassays as well as the resulted minimum inhibitory, minimum bactericidal, and minimum fungicidal concentrations have been reported in our previous paper [18].

\section{ALR2 preparation}

Lenses were quickly removed from male Wistar rats following euthanasia. The animals came from the Breeding Facility of the Institute of Experimental Pharmacology and Toxicology, Dobra Voda (Slovak Republic). The study was approved by the Ethics Committee of the Institute and performed in accordance with the Principles of Laboratory Animal Care (NIH publication 83-25, revised 1985) and the Slovak law regulating animal experiments (Decree 289, Part 139, July 9, 2003). The animals in light ether anesthesia were killed by exsanguinations of the carotid artery and the eye globes were excised. The lenses were quickly dissected and rinsed with saline. ALR2 from rat lens was partially purified according to the reported procedure as follows [41]: lenses were quickly removed from rats following euthanasia and stored at $-80{ }^{\circ} \mathrm{C}$ until used. The lenses were homogenized in a glass homogenizer with a teflon pestle in $5 \mathrm{vol}$ of cold distilled water. The homogenate was centrifuged at $10.000 \mathrm{~g}$ at $0-4{ }^{\circ} \mathrm{C}$ for $15 \mathrm{~min}$. The supernatant was repeatedly precipitated with saturated ammonium sulfate at $40 \%, 50 \%$, and then at $75 \%$ salt saturation and these solutions were centrifuged at $10.000 \mathrm{~g}$ at $0-4{ }^{\circ} \mathrm{C}$ for $15 \mathrm{~min}$. The supernatants after the first two precipitations were retained. The pellet from the last step, possessing ALR2 activity, was either used directly or was dispersed in $75 \%$ ammonium sulfate and stored in smaller aliquots at $-80{ }^{\circ} \mathrm{C}$.

\section{ALR1 preparation}

Kidneys were quickly removed from male Wistar rats following euthanasia. The animals came from the Breeding Facility of the Institute of Experimental Pharmacology and Toxicology, Dobra Voda (Slovak Republic). The study was approved by the Ethics Committee of the Institute and performed in accordance with the Principles of Laboratory Animal Care (NIH publication 83-25, revised 1985) and the Slovak law regulating animal experiments (Decree 289, Part 139, July 9, 2003). ALR1 from rat kidney was partially purified according to the reported procedure as follows [41]: kidneys were homogenized in a knife homogenizer followed by processing in a glass homogenizer with a teflon pestle in 3 vol of $10 \mathrm{mM}$ sodium phosphate buffer, $\mathrm{pH} 7.2$, containing $0.25 \mathrm{M}$ sucrose, $2.0 \mathrm{mM}$ EDTA dipotassium salt, and $2.5 \mathrm{mM}$ 2-mercaptoethanol. The homogenate was centrifuged at $10.000 \mathrm{~g}$ at $0-4{ }^{\circ} \mathrm{C}$ for $30 \mathrm{~min}$ and the supernatant was subjected to ammonium sulfate fractional precipitation at $40 \%, 50 \%$, and $75 \%$ salt saturation. The pellet obtained from the last step, possessing ALR1 activity, was redissolved in $10 \mathrm{mM}$ sodium phosphate buffer, $\mathrm{pH}$ 7.2, containing $2.0 \mathrm{mM}$ EDTA dipotassium salt and $2.0 \mathrm{mM}$ 2-mercaptoethanol to achieve total protein concentration of approx. $20 \mathrm{mg} / \mathrm{mL}$. DEAE DE 52 resin was added to the solution $(33 \mathrm{mg} / \mathrm{mL})$ and after gentle mixing for $15 \mathrm{~min}$ removed by centrifugation. The supernatant containing ALR1 was then stored in smaller aliquots at $-80^{\circ} \mathrm{C}$. No appreciable contamination by ALR2 in ALR1 preparations was detected since no activity, in terms of NADPH consumption, was observed in the presence of glucose substrate up to $150 \mathrm{mM}$.

\section{ALR2/ALR1 enzyme assays}

ALR2 and ALR1 activities were assayed spectrophotometrically by determining NADPH consumption at $340 \mathrm{~nm}$ with a UV/Vis Perkin-Elmer Spectrometer Lamda 20 [41]. In order to determine ALR2 inhibitory activity D, L-glyceraldehyde was used as substrate and the measurements took place in $0.067 \mathrm{M}$ phosphate buffer $\mathrm{pH} 6.2$ at $30{ }^{\circ} \mathrm{C}$, whereas ALR1 inhibitory activity was determined with D-glucuronate as a substrate and the measurements took place in $0.1 \mathrm{M}$ phosphate buffer, $\mathrm{pH} 7.2$ at $37^{\circ} \mathrm{C}$. All compounds were dissolved in $0.2 \mathrm{M} \mathrm{NaHCO}_{3}$ or DMSO ( $1 \%$ final concentration). The reference blank contained all 
the above reagents except the substrate to make correction for oxidation of NADPH not associated with reduction of the substrate. The enzyme reaction was initiated by addition of a substrate. Then, the $\log$ (concentration)-response curves were constructed from the inhibitory data, and the $\mathrm{IC}_{50}$ values were calculated by the least square analysis of the linear portion of the semi-logarithmic inhibition curves. Minimum two independent experiments were performed for inhibitor concentrations causing inhibition in the range at least $25-75 \%$.

\section{In silico studies}

\section{Pan-assay interference compounds screening}

It is known that 5-ene-thiazolidinones are assigned as frequent hitters or pan-assay interference compounds (PAINS) within high-throughput screening campaigns [42]. Therefore, all thiazolidinone derivatives in this study were screened through in silico filter (http://advisor.docking.org) to exclude potentially false positive compounds with nonspecific interactions (PAINS) and compounds with ability to form aggregates [43]. All the compounds passed this filter and no structural alerts were announced.

\section{PASS prediction}

PASS (Prediction of Activity Spectra for Substances) [35, 36] estimates that potential biological activities of compounds form a list of about 4000 reported biological activities with an average accuracy of $95 \%$. The program uses as input data the compounds' structures as MOL or SDF files. The results for all predictions are given as a list of possible activities with two statistic values that reveal the probability of compounds belonging to active $\left(P_{a}\right)$ and inactive $\left(P_{i}\right)$ classes. In case of high $P_{a}$ values, it could be assumed that there are closely related analogs in the PASS training set. On the other hand, compounds with $P_{a}$ values lower than 0.5 will have not close analogs in training set and could be NCE.

\section{Physicochemical properties}

It has been established that an acidic carboxymethyl group is the key pharmacophoric feature of the most efficient ARIs [8]. However, carboxylic acid derivatives exhibit low pKa values resulting in high ionization at physiological blood $\mathrm{pH}$. Moreover, they show poor tissue penetration and as a result, low in vivo activity [44]. Owing to low pKa value of the acidic function, acidic ARIs are ionized at the physiological $\mathrm{pH}$ that hampers their crossing through biomembranes, eventually resulting in low bioavailability. The $\mathrm{pKa}$ of the carboxymethyl group, e.g., in epalrestat is around 4.7. Thus, most of the compound is ionized at $\mathrm{pH} 7.4$.
Therefore, ARIs with higher pKa values are searched for. Since it is significant for ARIs to be highly permeable through biological barriers and, in general, orally active, we performed a screening of our compounds through Lipinski's "rule of five" and Veber's criteria. The values of MW, hydrogen bond donors (HBD), HBA, TPSA, and the number of rotatable bonds (NRB) [41] were calculated by ADME Boxes 3.0 and are shown in Table 2.

\section{Docking analysis}

All 3D structures of compounds were sketched in Discovery Studio 2020 (BIOVIA) software and then saved as Sybyl2 (mol2) files. Lowest energy conformations of all compounds were generated using the MMFF94 energy minimization protocol in the LigandScout program [45]. Molecular docking simulations were performed on LigandScout software by using Autodock 4.2. Default docking settings were applied and the binding affinity was calculated in $\mathrm{kcal} / \mathrm{mol}$. The lowest docking energy complex in terms of root means square deviation value was then selected as the most favorable pose for each compound.

The crystal structure of human ALR2 in complex with epalrestat (Protein Data Bank, PDB: 4JIR) was used in the docking analysis. Although the in vitro inhibition assays of our compounds were conducted on rat ALR2, the use of the human ALR2 structure for docking is justified by the facts that the crystal structure of rat ALR2 co-crystallized with inhibitors is not yet available and human and rat ALR2 sequences share $85 \%$ identity [37].

Acknowledgements This research was funded by VEGA 2/0005/ 2018. We are thankful to Prof. Anna Tsantili-Kakoulidou, Department of Pharmaceutical Chemistry, School of Pharmacy, National and Kapodistrian University of Athens, Athens, Greece for the permission to use the Pallas 3.1 and ADME boxes 3.0 programs.

\section{Compliance with ethical standards}

Conflict of interest The authors declare no competing interests.

Publisher's note Springer Nature remains neutral with regard to jurisdictional claims in published maps and institutional affiliations.

\section{References}

1. Rudd KE, Johnson SC, Agesa KM, Shackelford KA, Tsoi D, Kievlan DR, et al. Global, regional, and national sepsis incidence and mortality, 1990-2017: analysis for the Global Burden of Disease Study. Lancet. 2020;395:200-11. https://doi.org/10.1016/ S0140-6736(19)32989-7

2. Haque M, Sartelli M, McKimm J, Bakar MA. Health careassociated infections - an overview. Infect Drug Resist. 2018;11:2321-33. https://doi.org/10.2147/IDR.S177247 
3. Shoeb M, Ramana K. Aldose reductase: a potential drug target for the treatment of sepsis complications. J Biochem Pharm Res. 2013;1:168-75.

4. Nedeva C, Menassa J, Puthalakath H. Sepsis: inflammation is a necessary evil. Front Cell Dev Biol. 2019;7:1-12. https://doi.org/ 10.3389/fcell.2019.00108

5. Ramana KV, Willis MS, White MD, Horton JW, Dimaio JM, Srivastava D, et al. Endotoxin-induced cardiomyopathy and systemic inflammation in mice is prevented by aldose reductase inhibition. Circulation. 2006;114:1838-46. https://doi.org/10. 1161/CIRCULATIONAHA.106.630830

6. Pandey S, Srivastava SK, Ramana KV. A potential therapeutic role for aldose reductase inhibitors in the treatment of endotoxinrelated inflammatory diseases. Expert Opin Investig Drugs. 2012;21:329-39. https://doi.org/10.1517/13543784.2012.656198

7. Reddy AB, Srivastava SK, Ramana KV. Anti-inflammatory effect of aldose reductase inhibition in murine polymicrobial sepsis. Cytokine. 2009;48:170-6. https://doi.org/10.1016/j.cyto.2009.07.004

8. Kousaxidis A, Petrou A, Lavrentaki V, Fesatidou M, Nicolaou I, Geronikaki A. Aldose reductase and protein tyrosine phosphatase $1 \mathrm{~B}$ inhibitors as a promising therapeutic approach for diabetes mellitus. Eur J Med Chem. 2020;207:112742-84. https://doi.org/ 10.1016/j.ejmech.2020.112742

9. Ravindranath TM, Mong PY, Ananthakrishnan R, Li Q, Quadri N, Schmidt AM, et al. Novel role for aldose reductase in mediating acute inflammatory responses in the lung. J Immunol. 2009;183:8128-37. https://doi.org/10.4049/jimmunol.0900720

10. Yadav UCS, Shoeb M, Srivastava SK, Ramana KV. Aldose reductase deficiency protects from autoimmune- and endotoxininduced uveitis in mice. Investig Ophthalmol Vis Sci. 2011;52:8076-85. https://doi.org/10.1167/iovs.11-7830

11. Takahashi K, Mizukami H, Kamata K, Inaba W, Kato N, Hibi C, et al. Amelioration of acute kidney injury in lipopolysaccharideinduced systemic inflammatory response syndrome by an aldose reductase inhibitor, Fidarestat. PLoS One. 2012;7:1-11. https:// doi.org/10.1371/journal.pone.0030134

12. Ramana KV. Aldose reductase: new insights for an old enzyme. Biomol Concepts. 2011;2:103-14. https://doi.org/10.1515/bmc. 2011.002

13. Kadosh BS, Garshick MS, Gaztanaga J, Moore KJ, Newman JD, Pillinger M, et al. COVID-19 and the heart and vasculature: novel approaches to reduce virus-induced inflammation in patients with cardiovascular disease. Arterioscler Thromb Vasc Biol. 2020;40:2045-53. https://doi.org/10.1161/ATVBAHA.120.314513

14. Coyle J, Igbinomwanhia E, Sanchez-Nadales A, Danciu S, Chu C, Shah N. A recovered case of COVID-19 myocarditis and ARDS treated with corticosteroids, tocilizumab, and experimental AT001. JACC Case Rep. 2020;2:1331-6. https://doi.org/10.1016/j.ja ccas.2020.04.025

15. Jose M, Desai K. Fatal superimposed bacterial sepsis in a healthy coronavirus (COVID-19) patient. Cureus. 2020;12:2045-50. https://doi.org/10.7759/cureus.8350

16. Beltrán-García J, Osca-Verdegal R, Pallardó FV, Ferreres J, Rodríguez M, Mulet S, et al. Sepsis and coronavirus disease 2019: common features and anti-inflammatory therapeutic approaches. Crit Care Med. 2020;48:1841-4. https://doi.org/10.1097/ccm. 0000000000004625

17. Liaras K, Geronikaki A, Glamočlija J, Ćirić A, Soković M. Thiazole-based chalcones as potent antimicrobial agents. Synthesis and biological evaluation. Bioorg Med Chem. 2011;19:3135-40. https://doi.org/10.1016/j.bmc.2011.04.007

18. Haroun M, Tratrat C, Kositzi K, Tsolaki E, Petrou A, Aldhubiab $\mathrm{B}$, et al. New benzothiazole-based thiazolidinones as potent antimicrobial agents. Design, synthesis and biological evaluation. Curr Top Med Chem. 2018;18:75-87. https://doi.org/10.2174/ 1568026618666180206101814
19. Haroun M, Tratrat C, Tsolaki E, Geronikaki A. Thiazole-based thiazolidinones as potent antimicrobial agents. Design, synthesis and biological evaluation. Comb Chem High Throughput Screen. 2016;19:51-7. https://doi.org/10.2174/138620731966615120300 2348

20. Ali S, Saeed A, Abbas N, Shahid M, Bolte M, Iqbal J. Design, synthesis and molecular modelling of novel methyl[4-oxo-2(aroylimino)-3-(substituted phenyl)thiazolidin-5-ylidene]acetates as potent and selective aldose reductase inhibitors. MedChemComm. 2012;3:1428-34. https://doi.org/10.1039/c2md20228j.

21. Khan N, Gautam G, Gupta AK. Synthesis and biological evaluation of some new rhodanine analogues as aldose reductase inhibitors (ARIs). J Drug Deliv Ther. 2019;9:161-7. https://doi. org/10.22270/jddt.v9i1-s.2284

22. Rakowitz D, Maccari R, Ottanà R, Vigorita MG. In vitro aldose reductase inhibitory activity of 5-benzyl-2,4-thiazolidinediones. Bioorg Med Chem. 2006;14:567-74. https://doi.org/10.1016/j. bmc.2005.08.056

23. Maccari R, Ottanà R, Ciurleo R, Vigorita MG, Rakowitz D, Steindl $\mathrm{T}$, et al. Evaluation of in vitro aldose redutase inhibitory activity of 5-arylidene-2,4-thiazolidinediones. Bioorg Med Chem Lett. 2007;17:3886-93. https://doi.org/10.1016/j.bmcl.2007.04.109

24. Maccari R, Ottanà R, Curinga C, Vigorita MG, Rakowitz D, Steindl $\mathrm{T}$, et al. Structure-activity relationships and molecular modelling of 5-arylidene-2,4-thiazolidinediones active as aldose reductase inhibitors. Bioorg Med Chem. 2005;13:2809-23. https://doi.org/10.1016/j.bmc.2005.02.026

25. Maccari R, Ottanà R, Ciurleo R, Rakowitz D, Matuszczak B, Laggner C, et al. Synthesis, induced-fit docking investigations, and in vitro aldose reductase inhibitory activity of non-carboxylic acid containing 2,4-thiazolidinedione derivatives. Bioorg Med Chem. 2008;16:5840-52. https://doi.org/10.1016/j.bmc.2008.04.072

26. Maccari R, Ciurleo R, Giglio M, Cappiello M, Moschini R, Del Corso A, et al. Identification of new non-carboxylic acid containing inhibitors of aldose reductase. Bioorg Med Chem. 2010;18:4049-55. https://doi.org/10.1016/j.bmc.2010.04.016

27. Maccari R, Del Corso A, Giglio M, Moschini R, Mura U, Ottanà $\mathrm{R}$. In vitro evaluation of 5-arylidene-2-thioxo-4-thiazolidinones active as aldose reductase inhibitors. Bioorg Med Chem Lett. 2011;21:200-3. https://doi.org/10.1016/j.bmcl.2010.11.041

28. Metwally K, Pratsinis H, Kletsas D, Quattrini L, Coviello V, La Motta C, et al. Novel quinazolinone-based 2,4-thiazolidinedione3 -acetic acid derivatives as potent aldose reductase inhibitors. Future Med Chem. 2017;9:2147-66. https://doi.org/10.4155/fmc2017-0149

29. Ottanà R, Paoli $\mathrm{P}, \mathrm{Naß} \mathrm{A}$, Lori G, Cardile V, Adornato I. et al. Discovery of 4-[(5-arylidene-4-oxothiazolidin-3-yl)methyl]benzoic acid derivatives active as novel potent allosteric inhibitors of protein tyrosine phosphatase 1B: in silico studies and in vitro evaluation as insulinomimetic and anti-inflammatory agents. Eur J Med Chem. 2017;127:840-58.https://doi.org/10.1016/j.ejmech.2016.10.063.

30. Ottanà R, Maccari R, Giglio M, Del Corso A, Cappiello M, Mura $\mathrm{U}$, et al. Identification of 5-arylidene-4-thiazolidinone derivatives endowed with dual activity as aldose reductase inhibitors and antioxidant agents for the treatment of diabetic complications. Eur J Med Chem. 2011;46:2797-2806. https://doi.org/10.1016/j. ejmech.2011.03.068

31. Sambasivarao SV, Soni LK, Gupta AK, Hanumantharao P, Kaskhedikar SG. Quantitative structure-activity analysis of 5-arylidene-2,4- thiazolidinediones as aldose reductase inhibitors. Bioorg Med Chem Lett. 2006;16:512-20. https://doi.org/10.1016/j.bmcl. 2005.10.069

32. Soni LK, Gupta AK, Kaskhedikar SG. QSAR study of 5-arylidene-2,4-thiazolidinediones as aldose reductase inhibitors. Med Chem Res. 2008;17:258-66. https://doi.org/10.1007/s00044-0079061-4 
33. Kucerova-Chlupacova M, Halakova D, Majekova M, Treml J, Stefek M, Soltesova Prnova M. (4-Oxo-2-thioxothiazolidin-3-yl) acetic acids as potent and selective aldose reductase inhibitors. Chem Biol Interact. 2020;332:109286-7. https://doi.org/10.1016/ j.cbi.2020.109286

34. Bruno G, Costantino L, Curinga $\mathrm{C}$, Maccari R, Monforte $\mathrm{F}$, Nicolò $\mathrm{F}$, et al. Synthesis and aldose reductase inhibitory activity of 5arylidene-2,4-thiazolidinediones, Bioorganic. Med Chem. 2002;10:1077-84. https://doi.org/10.1016/S0968-0896(01)00366-2

35. Filimonov D, Lagunin AA, Gloriozova TA, Rudik A, Druzhilovskii DS, Pogodin PV, et al. Prediction of the biological activity spectra of organic compounds using the pass online web resource. Chem Heterocycl Compd. 2014;50:444-57. https://doi.org/10. 1007/s10593-014-1496-1

36. Poroikov VV. Computer-aided drug design: from discovery of novel pharmaceutical agents to systems pharmacology. Biochem Suppl Ser B Biomed Chem. 2020;14:216-27. https://doi.org/10. 1134/s1990750820030117

37. Chatzopoulou M, Patsilinakos A, Vallianatou T, Prnova MS, Žakelj S, Ragno R, et al. Decreasing acidity in a series of aldose reductase inhibitors: 2-Fluoro-4-(1H-pyrrol-1-yl)phenol as a scaffold for improved membrane permeation. Bioorg Med Chem. 2014;22:2194-207. https://doi.org/10.1016/j.bmc.2014.02.016

38. Celestina SK, Sundaram S, Ravi S. In vitro studies of potent aldose reductase inhibitors: synthesis, characterization, biological evaluation and docking analysis of rhodanine-3-hippuric acid derivatives. Bioorg Chem. 2020;97:103640-7. https://doi.org/10. 1016/j.bioorg.2020.103640
39. Majekova M, Ballekova J, Prnova M, Stefek M. Structure optimization of tetrahydropyridoindole-based aldose reductase inhibitors improved their efficacy and selectivity. Bioorg Med Chem. 2017;25:6353-60. https://doi.org/10.1016/j.bmc.2017.10.005

40. Kato A, Kobayashi K, Narukawa K, Minoshima Y, Adachi I, Hirono S, et al. 6,7-Dihydroxy-4-phenylcoumarin as inhibitor of aldose reductase 2. Bioorg Med Chem Lett. 2010;20:5630-3. https://doi.org/10.1016/j.bmcl.2010.08.038

41. Papastavrou N, Chatzopoulou M, Ballekova J, Cappiello M, Moschini R, Balestri F, et al. Enhancing activity and selectivity in a series of pyrrol-1-yl-1-hydroxypyrazole-based aldose reductase inhibitors: the case of trifluoroacetylation. Eur J Med Chem. 2017;130:328-35. https://doi.org/10.1016/j.ejmech.2017.02.053

42. Kaminskyy D, Kryshchyshyn A, Lesyk R. 5-Ene-4thiazolidinones - an efficient tool in medicinal chemistry. Eur $\mathbf{J}$ Med Chem. 2017;140:542-94. https://doi.org/10.1016/j.ejmech. 2017.09.031

43. Baell JB, Holloway GA. New substructure filters for removal of pan assay interference compounds (PAINS) from screening libraries and for their exclusion in bioassays. J Med Chem. 2010;53:2719-40. https://doi.org/10.1021/jm901137j

44. Manallack DT, Prankerd RJ, Yuriev E, Oprea TI, Chalmers DK. The significance of acid/base properties in drug discovery. Chem Soc Rev. 2013;42:485-96. https://doi.org/10.1039/c2cs35348b

45. Wolber G, Langer T. LigandScout: 3-D pharmacophores derived from protein-bound ligands and their use as virtual screening filters. J Chem Inf Model. 2005;45:160-9. https://doi.org/10.1021/ ci049885e 